\title{
The Economic Value of Intellectual Capital and Patents in South Korea
}

\author{
S. Lim and T. Ryu
}

\begin{abstract}
As knowledge is key resource in national growth, understanding the distribution of intellectual capital across the national economic sector should precede national policy making for the strength of national competitiveness. This study measure the value of intellectual capital and patent using dataset covering financial statements of 18,733 firms and 214,405 firm-year observations in the period of 1995 2011. The resulting value of intellectual capital is $\mathbf{5 7 . 4}$ billion Korean won in 2010, which is about $\mathbf{5 2 . 1 \%}$ of GDP. And the patent related value in intellectual capital is $\mathbf{4 . 5}$ billion Korean won, which is $8 \%$ of intellectual capital and $40 \%$ of structural capital of a firm in average.
\end{abstract}

Index Terms-Intellectual capital, CIV, capitalization, patent.

\section{INTRODUCTION}

In knowledge based economic paradigm, knowledge is key resource in national growth. Recent study [1] shows that the impact of innovation on U.S. economic growth was increased from 25\% during 1997 1995 to 35\% during 1996 2003. World Bank study also found that a $20 \%$ increase in the number of patents is associated with $3.8 \%$ increase in economic output [2].

The growing importance of knowledge is accompanied by the necessity of measuring the national intellectual capital. Understanding the distribution of intellectual capital across the national economic sector should precede national policy making for the strength of national competitiveness.

The term 'intellectual capital' is often used as a synonym of 'intangible assets' or 'knowledge capital'. Recently the 'intellectual capital' is considered as a subset of 'intangible assets' [3]. Reference [4] defines 'intellectual capital' as a set of intellectual properties (patents, copyrights, and so on), database, management knowhow and economic idea.

This study measure the economic value of intellectual capital of South Korea in the period of 1997 2011 using CIV (Calculated Intangible Value) method developed by [5]. CIV method is a firm based measurement tool for the monetary value of intellectual capital. And, this study classifies the intellectual capital to human capital, structural capital and customer capital using the information of balance sheet of firms. Finally, we measure the economic value of patents which is a part of structural capital.

Manuscript received April 21, 2013; revised July10, 2013

This study is sponsored by Korean Intellectual Property Office in 2012.

So-Jin Lim is with Korea Institute of Intellectual Property, South Korea (e-mail: sjlim@kiip.re.kr).

\section{MeAsurement OF InTEllectual CAPitAl}

\section{A. Methodology and Data}

The methodologies for measuring the monetary value of intellectual capital are largely divided to market capitalization (MC) approach and return on assets (ROA) approach. MC approach assumes intangible assets including intellectual capital is calculated by subtracting the tangible book value from the market capitalization of a given company. Previous studies often use MC approach because of its convenience. However there are many limitations that the intellectual capital calculated by MC approach is sensitive to short term economic fluctuation, and it can be applicable only to public companies with market value. This study adopts ROA approach which assumes the intellectual capital as excess return of tangible assets. Among ROA approaches, we select Calculated Intangible Value (CIV) developed by the NCI Research group [5]. In CIV method, the intellectual capital is defined as "firm's ability to use its intangible assets to outperform other firms in its industry.

The calculation step of a firm's intellectual capital using CIV method is as follows.

- Calculate the firm's average pretax earnings for the past three years.

- Calculate the firm's average tangible assets for the past three years.

- Calculate the industry average return on assets (ROA) for the same three-year period as in Step 2.

- Calculate the firm's excess return by subtracting the product of the industry average ROA by the average tangible assets calculated in Step 2 from the pretax earnings.

- Calculate the three-year average corporate tax rate and multiply by the excess return. Deduct the result from the excess return.

- Calculate the net present value of the after-tax excess return. Use the firm's cost of capital as a discount rate. We calculate the firm's cost of capital using capital asset pricing model (CAPM).

National intellectual capital is in not only firms seeking profit but also the non-profit organizations including public research institutes, universities and associations. However, to measure its economic value, the owner should acquire economic benefit through utilizing the intellectual capital.

Therefore we include only firms, which have an external audit because of their asset size more than 7 billion won. The total dataset includes financial statements of 18,733 
non-financial firms in the period of 1995 2011, resulting 214,405 firm-year observations.

\section{B. Results}

Table I shows the result of measuring monetary value of intellectual capital in the period of 1997 2011. The value is sharply increased from 5.14 billion Korean won in 1997 to 55.5 billion Korean won in 2011.

TABLE I: THE VALUE OF INTELLECTUAL CAPITAL

\begin{tabular}{lll}
\hline Year & $\begin{array}{l}\text { Sum of intellectual capital } \\
\text { (billion Korean won) }\end{array}$ & Number of firms \\
\hline 1997 & 5.14 & 6,456 \\
1998 & 4.47 & 7,269 \\
1999 & 6.16 & 8,999 \\
2000 & 9.84 & 10,019 \\
2001 & 9.83 & 10,891 \\
2002 & 16.3 & 11,816 \\
2003 & 20.8 & 12,504 \\
2004 & 30.9 & 13,129 \\
2005 & 26.6 & 13,771 \\
2006 & 23.6 & 14,674 \\
2007 & 26.9 & 15,562 \\
2008 & 32.5 & 16,307 \\
2009 & 40.0 & 17,209 \\
2010 & 57.4 & 17,980 \\
2011 & 55.5 & 17,756 \\
\hline \hline
\end{tabular}

As for the industrial distribution of intellectual capital, the ratios of intellectual capital in agriculture, mining, paper ware manufacturing industries decreased, and the ratios of intellectual capital in chemical product, precision instrument, automobile manufacturing and recycling, environmental remediation industry sharply increased in the period of 1997 2011.

\section{Composition OF InTEllectual CAPITAL}

\section{A. Three Categories of Intellectual Capital}

The intellectual capital of firms can be categorized to three parts: human capital, structural capital and customer (or relational) capital.

TABLE II: THREE CATEGORIES OF INTELLECTUAL CAPITAL

\begin{tabular}{ll}
\hline Type & Definition \\
\hline Human capital & $\begin{array}{l}\text { Specialty, experience, problem solving skill, } \\
\text { leadership, entrepreneurship creativity of } \\
\text { employee }\end{array}$ \\
& $\begin{array}{l}\text { Infrastructure, organization process, information } \\
\text { system, intellectual property (patent, design, } \\
\text { business secret, know-how) }\end{array}$ \\
Structural capital & $\begin{array}{l}\text { Brand, relationship with customers and suppliers, } \\
\text { industry network, distribution channels }\end{array}$ \\
\hline \hline
\end{tabular}

Table II shows the definition of each capital. However, those three capitals are not exclusive and interact with each other. Therefore it is very difficult to separate human, structural and customer capital based on an objective standard.

\section{B. Methodology}

\section{1) Categorize expenditure on human, structural and} customer capital

The primary information about the composition of intellectual capital is a firm's expenditure on each type of capital. For examples, if a firm's R\&D expenditure takes a larger share of total cost, the firm might have more structural capital than other firms.

Table III shows the result. The ratio of expenditure related to human capital is decreased from $63 \%$ in 1997 to $55 \%$ in 2011 , and the ratio of structural capital related expenditure has doubled in the same period.

\section{TABLE III: THE COMPOSITION OF EXPENDITURE}

\begin{tabular}{llll}
\hline \hline Year & $\begin{array}{l}\text { Human capital } \\
\text { related }\end{array}$ & $\begin{array}{l}\text { Structural capital } \\
\text { related }\end{array}$ & $\begin{array}{l}\text { Customer capital } \\
\text { related }\end{array}$ \\
\hline 1997 & 0.63 & 0.06 & 0.31 \\
1998 & 0.60 & 0.05 & 0.34 \\
- & - & - & - \\
2009 & 0.53 & 0.13 & 0.34 \\
2010 & 0.53 & 0.11 & 0.36 \\
2011 & 0.55 & 0.10 & 0.35 \\
\hline \hline
\end{tabular}

\section{Measure the Contribution Ratio of Intellectual Capital Related Expenditure}

However the effects of expenditures related to human, structural and customer capital are different each other on the firm's intellectual capital. Thus we should examine how much the intellectual capital related expenditures are capitalized to a firm's intellectual capital.

Many studies on the capitalization of costs related to intellectual capital are focused on labor costs and R\&D expenditure. As a study on the capitalization of $R \& D$ expenditure, [6] shows positive relationship between price-earnings ratio and profit calculated after capitalization of R\&D expenditure. Reference [7] examines the value of firms' R\&D expenditure using [8]'s residual income model (RIM) and models the capitalizing process of $R \& D$ expenditure. As a study on the capitalization of labor costs, [9] measures the value of human capital by capitalizing labor costs using RIM. Reference [9] shows the depreciation ratio of human capital is $34 \%$ and the human capital contributes to $5 \%$ of firm's value.

To examine how much costs related to intellectual capital are capitalized to firm value, this study use the firm value equation (1) considering the capitalization of intellectual capital related costs [6], [7], [9], [10].

$$
\begin{gathered}
V_{t}=A_{t}-\left[\frac{\omega}{1+R-\omega} R\right] A_{t-1}+\frac{\omega}{1+R-\omega} E_{t} \\
+\left[1-\frac{\omega}{1+R-\omega} R\right] \frac{\alpha_{h}}{\delta_{h}} Z_{h t}+\left[1-\frac{\omega}{1+R-\omega} R\right] \frac{\alpha_{s}}{\delta_{s}} Z_{s t} \\
+\left[1-\frac{\omega}{1+R-\omega} R\right] \frac{\alpha_{c}}{\delta_{c}} Z_{c t}
\end{gathered}
$$


where $V_{t}$ : firm value at time $t, A_{t}$ : total assets at time $t$, $\omega$ :durability of excess earnings, $R$ : cost of equity capital, $E_{t}$ : business profits at time $t, \alpha_{h}, \alpha_{s}, \alpha_{c}$ : conversion rate of human, structural and customer capital related costs to assets, $\delta_{h}, \delta_{s}, \delta_{c}$ : depreciation rate of human, structural and customer capital, $Z_{h t}, Z_{s t}, Z_{c t}$ : human, structural and customer capital related costs at time $t$.

$\frac{\alpha}{\delta}$ is the conversion multiplier of intellectual capital related costs. The assumption of equation (1) is that the intellectual capital related costs remains steady in the future. In the equation (1), the firm value $V_{t}$ including both tangible and intangible assets is expressed by observable opened information in financial statements.

We estimate $\omega, R, \frac{\alpha_{h}}{\delta_{h}}, \frac{\alpha_{s}}{\delta_{s}}, \frac{\alpha_{c}}{\delta_{c}}$ in equation (1) using non-linear least square regression.

\section{Results}

The resulting value of estimation is as follows. The conversion multipliers of human, structural and customer capital related costs are 1.015, 2.011 and 1.546 respectively. It means the expenditure on structural capital contributes twice as effective as that on human capital on a firm's intellectual capital.

TABLE IV: RESULTS OF NON-LINEAR REGRESSION

\begin{tabular}{lll}
\hline \hline & coefficient & t-value \\
\hline $\mathrm{R}$ & 0.847 & 3.015 \\
$\frac{\alpha_{h}}{\delta_{h}}$ & 0.019 & 6.335 \\
$\frac{\alpha_{s}}{\delta_{\mathrm{c}}}$ & 1.015 & 2.044 \\
$\frac{\alpha_{c}}{\delta}$ & 2.011 & 9.364 \\
\hline \hline
\end{tabular}

TABLE V: THE COMPOSITION OF INTELLECTUAL CAPITAL

\begin{tabular}{llll}
\hline \hline Year & Human capital & Structural capital & Customer capita \\
\hline 1997 & $54.00 \%$ & $9.70 \%$ & $36.30 \%$ \\
1998 & $57.40 \%$ & $9.70 \%$ & $32.90 \%$ \\
1999 & $47.20 \%$ & $13.40 \%$ & $39.40 \%$ \\
2000 & $39.50 \%$ & $24.40 \%$ & $36.00 \%$ \\
2001 & $46.10 \%$ & $17.70 \%$ & $36.20 \%$ \\
2002 & $41.80 \%$ & $23.10 \%$ & $35.10 \%$ \\
2003 & $41.40 \%$ & $22.00 \%$ & $36.60 \%$ \\
2004 & $42.10 \%$ & $25.40 \%$ & $32.50 \%$ \\
2005 & $44.30 \%$ & $24.10 \%$ & $31.60 \%$ \\
2006 & $45.80 \%$ & $23.60 \%$ & $30.60 \%$ \\
2007 & $45.40 \%$ & $19.90 \%$ & $34.70 \%$ \\
2008 & $43.10 \%$ & $18.70 \%$ & $38.20 \%$ \\
2009 & $44.20 \%$ & $19.90 \%$ & $35.90 \%$ \\
2010 & $42.60 \%$ & $20.10 \%$ & $37.30 \%$ \\
2011 & $44.20 \%$ & $17.40 \%$ & $38.40 \%$ \\
\hline \hline
\end{tabular}

Using the resulting conversion multipliers and actual expenditure on human, structural and customer capital of each firm, we calculate the composition of firms' intellectual capital as Table V. In this study, we assume that the firm's intellectual capital is composed by only human, structural and customer capital.

The time trend in Table V shows that the structural capital including intellectual property, infrastructure, organizational process supporting human and customer capital is becoming a more important factor in intellectual capital than human capital.

\section{The Economic VAlue of PATENTS}

\section{A. Model}

In the early stage of innovation research, the variable of R\&D investment was used as a proxy for innovation of a firm. However, there are many limitations because the information on $\mathrm{R} \& \mathrm{D}$ investment is not accurate and the relationship with knowledge is not significant.

Later studies [11], [12] use the variable of patents as an index for innovation. The patent data has the information on the 'success' of R\&D investment. To solve the problem of non-uniformly distributed value across patents, additional information about the patent quality including citation [13], renewal [14], [15], and the number of claims is considered.

In this sector, we estimate the effects of applied patents, granted patents and the quality of patents on a firm's intellectual capital for measuring the patent related monetary value. We regress equation (2) using two way fixed effect panel model, which could consider the time and firm effect.

$$
V_{i t}=f\left(P A T_{-} A P_{i t}, \frac{P A T_{-} G R_{i t}}{P A T_{-} A P_{i t}}, \frac{P A T_{-} C L_{i t}}{P A T_{-} G R_{i t}}\right)
$$

$P A T_{-} A P_{i t}:$ applied patent stock of firm $i$ at time $t$

$P A T_{-} G R_{i t}$ : granted patent stock of firm $i$ at time $t$ $P A T_{-} C L_{i t}$ : claim stock of firm $i$ at time $t$

The effect of patents from R\&D on a firm's intellectual capital can be divided to three steps. Firstly, applied patent can be an index for successful R\&D. In equation (2), ' $P A T_{-} A P_{i t}$ ' is a variable for analyzing the effect of applied patents from R\&D on the increase of a firm's intellectual capital.

Secondly, as an applied patent is registered, it brings the firm additional profit by being commercialized. ' $\frac{P A T_{-} G R_{i t}}{P A T_{-} A P_{i t}}$

in equation (2) is granted patent stock of one unit of applied patent stock, and is for estimating the additional effect of registration of applied patent stock on a firm's intellectual capital.

Thirdly, a firm's intellectual capital is also influenced by the quality of granted patents. Because the citation information of patents is not available in South Korea, we use the number of claims of granted patents as an index for patent value. $\frac{P A T_{-} C L_{i t}}{P A T_{-} G R_{i t}}$ in equation (2) is an average number of claims of one unit of granted patent stock. 


\section{B. Variables and Data}

To calculate patent stock, we use following equation (3). We apply $30 \%$ depreciation ratio [16].

$$
\text { Patent stock } t=\text { Patent }_{t}+(1-\delta) \text { Patent stock }_{t-1}
$$$$
\delta \text { : the depreciation ratio of a patent }
$$

Table VI shows the other variables influencing a firm's intellectual capital. The influence factors are a firm's ability to yield profit [17], [18], asset value and its composition [19], [20], [18], financial solvency [18].

TABLE VI: DEFINITION OF VARIABLES

\begin{tabular}{|c|c|c|c|}
\hline & & Variable & Definition \\
\hline Sales scale & & Lnsalest & $\log$ (sales) \\
\hline \multirow{2}{*}{$\begin{array}{l}\text { Asset value } \\
\text { and its } \\
\text { composition }\end{array}$} & $\begin{array}{l}\text { Size of } \\
\text { asset }\end{array}$ & Lnasset & $\log$ (total assets) \\
\hline & $\begin{array}{l}\text { Ratio of } \\
\text { liquid } \\
\text { assets }\end{array}$ & Liq_asset & Liquid assets / total assets \\
\hline $\begin{array}{l}\text { Financial } \\
\text { solvency }\end{array}$ & $\begin{array}{l}\text { Debt-to-equ } \\
\text { ity ratio }\end{array}$ & Debt_ratio & $\begin{array}{l}\text { debt/total ownership } \\
\text { interest }\end{array}$ \\
\hline \multirow{5}{*}{ Innovation asset } & & $\ln R \& D$ & $\log (\mathrm{R} \& \mathrm{D}$ expenditure $)$ \\
\hline & & Mar_app & $\begin{array}{l}\text { Applied patent stock } \\
/ \log (\mathrm{R} \& \mathrm{D})\end{array}$ \\
\hline & & App & Applied patent stock \\
\hline & & Mar_gra & $\begin{array}{l}\text { Granted patent stock } \\
\text { /applied patent stock }\end{array}$ \\
\hline & & Mar_cla & $\begin{array}{l}\text { Claim stock } \\
\text { /granted patent stock }\end{array}$ \\
\hline \multicolumn{2}{|l|}{ Time effect } & \multicolumn{2}{|c|}{ Year dummy } \\
\hline \multicolumn{2}{|l|}{ Industry effect } & \multicolumn{2}{|c|}{ Considered in fixed panel model } \\
\hline
\end{tabular}

\section{Results}

Table VII shows the results of estimating two way fixed panel model. Model 1 includes the variables of $R \& D$ investment and applied patent stock per R\&D investment instead of applied patent stock. With the R\&D investment variable, the variable of applied patent stock per $R \& D$ investment is not significant. Model 2, 3 and 4 exclude the R\&D investment variable.

In the period of 1997 2011, three patent related variables applied patent stock, granted patent stock per applied patent stock and the average number of claims of granted patent stock - positively influence on a firm's intellectual capital.

The patent strategy of firms in South Korea has been changing from quantitative patenting to qualitative patenting since 2005. Thus we divide the period to pre- and post-2005. The effect of applied patent stock is negative in pre-2005 and positive in post-2005 on a firm's intellectual capital. It means that the quantitative patenting strategy regardless of the patent value could rather decrease the firm's intellectual capital.

The effect of granted patent stock per applied patent stock is significantly positive only in pre-2005, meaning that the patents which can positively influence on a firm's intellectual capital are registered in post-2005, but it is not in pre-2005.

Finally, the effect of the patent quality is positive only in pre-2005. This implies that the value is more non-uniformly distributed across the granted patent resulting from the patenting strategy regardless of the value in pre-2005. Thus the intellectual capital could be more fluctuated by the value of granted patents.

By using the coefficients in model 2, we estimate the patent related value in intellectual capital. As a result, the economic value of intellectual capital from patent is 4.5 billion Korean won in the year of 2010, which is about $8 \%$ of intellectual capital and $40 \%$ of structural capital. And the intellectual capital from the quality of patents was more sharply increased than that of applied and granted patents.

\begin{tabular}{|c|c|c|c|c|}
\hline & \multicolumn{2}{|c|}{ 1997 2011 } & \multirow{2}{*}{$\begin{array}{c}\text { 1997 2004 } \\
\text { Model } 3\end{array}$} & \multirow{2}{*}{$\begin{array}{c}\text { 2005 2011 } \\
\text { Model } 4\end{array}$} \\
\hline & Model 1 & Model 2 & & \\
\hline contant & $-7.49 \mathrm{E}+11^{* *}$ & $-9.18 \mathrm{E}+11^{* *}$ & $-5.19 \mathrm{E}+11 * *$ & $-1.13 \mathrm{E}+12 * *$ \\
\hline Lnsales $_{t}$ & $2.26 \mathrm{E}+10^{* *}$ & $2.51 \mathrm{E}+10^{* *}$ & $2.38 \mathrm{E}+10$ & $2.52 \mathrm{E}+10^{* *}$ \\
\hline Liq_asset $_{\mathrm{t}}$ & $5.58 \mathrm{E}+10^{* *}$ & $7.09 \mathrm{E}+10^{* *}$ & $3.84 \mathrm{E}+10$ & $6.65 \mathrm{E}+10^{* *}$ \\
\hline Debt_ratio $_{t}$ & $3.38 \mathrm{E}+05$ & 1514125 & 716741.5 & 937111.5 \\
\hline Lnasset $_{t}$ & $7.72 \mathrm{E}+09 *$ & $1.13 \mathrm{E}+10^{* *}$ & $-2.52 \mathrm{E}+09$ & $2.32 \mathrm{E}+10^{* *}$ \\
\hline $\ln R \& D_{t-1}$ & $2.24 \mathrm{E}+10 * *$ & - & - & - \\
\hline Mar_app & $1.03 \mathrm{E}+10$ & - & - & - \\
\hline $\mathrm{App}_{\mathrm{t}}$ & - & $1.37 \mathrm{E}+09 * *$ & $-5.84 \mathrm{E}+07 *$ & $9.44 \mathrm{E}+08 * *$ \\
\hline Mar_grat & $2.33 \mathrm{E}+10^{* *}$ & $2.00 \mathrm{E}+10^{* *}$ & $3.71 \mathrm{E}+09$ & $1.51 \mathrm{E}+10^{*}$ \\
\hline Mar_clat & $9.81 \mathrm{E}+07 *$ & $1.46 \mathrm{E}+08^{* *}$ & $2.42 \mathrm{E}+09^{* *}$ & $4.44 \mathrm{E}+07$ \\
\hline Year dummy & included & included & included & included \\
\hline
\end{tabular}

\section{CONCLUSION}

This study measures the economic value of intellectual capital and patents using CIV method and panel data analysis. The resulting value of intellectual capital is 57.4 billion Korean won in 2010, which is about $52.1 \%$ of GDP.

In intellectual capital is divided to human, structural and customer capital and those ratios are 43\%, 20\% and 37\% respectively. The ratio of structural capital is $20 \%$, while the ratio of structural capital related costs is $10 \%$. It means the expenditure on structural capital is more effective in increasing intellectual capital of the firm.

The patent related value in intellectual capital is 4.5 billion Korean won in 2010, which is $8 \%$ of intellectual capital and $40 \%$ of structural capital of a firm in average.

The information on the value distribution of national intellectual capital and patents shows the trend of industrial restructuring. The result of this study shows that the intellectual capital has been going from traditional industries over to chemical product, precision instrument, automobile manufacturing and recycling, environmental remediation industry.

\section{REFERENCES}

[1] B. A. Van, L. Barrington, G. Fosler, C. Hulten, and C. Woock, "Innovation and U.S. competitiveness: reevaluating the contributors to growth," Research Report 1441, The Conference Board, 2009.

[2] D. H. Chen and C. Dahlman, "Knowledge and development: a cross-section approach," World Bank Policy Research Working Paper, no. $3366,2004$. 
[3] OECD, "Measuring and reporting intellectual capital: experience, issues and prospects," Programme Notes and Background to Technical Meeting and Policy and Strategy Forum, Paris, 1999.

[4] K. A. Hassett and R. J. Shapiro. (2005). The economic value of intellectual property. [Online]. Available: http://www.sonecon.com/docs/studies/IntellectualPropertyReport-Oct ober2005.pdf

[5] T. A. Stewart, "Intellectual capital: the new wealth of organizations," New York: Doubleday Business, USA, 1997.

[6] B. Lev and T. Sougiannis, "The capitalization, amortization, and value-relevance of R\&D effect," Journal of Accounting and Economics, vol. 21, pp. 107-138, 1996.

[7] M. Ballester, M. Garcia-Ayuso, and J. Livnat, "Estimating the R\&D intangible asset," SSRN Working paper, New York University, 2000.

[8] J. A. Ohlson, "Earnings, book values, and dividends in equity valuation," Contemporary Accounting Research, vol. 11, no. 2, pp. 661-687, 1995.

[9] M. Ballester, J. Livnat, and N. Sinha, "Labor costs and investments in human capital," SSRN Working paper, 1999.

[10] W. Lee and S. Choi, "Empirical study on the valuation model and contribution of knowledge assets," Korean Journal of Financial Studies, vol. 30, no. 1, pp. 327-361.

[11] I. Cockburn and Z. Griliches, "Industry effects and appropriability measures in the stock market's valuation of R\&D and patents," American Economic Review, American Economic Association, vol. 78, no. 2, pp. 419-423, 1988.

[12] Z. Griliches, "Market value, R\&D, and patents," Economic Letters, vol. 7, pp. 183-187, 1981.

[13] M. Trajtenberg, "A penny for your quotes: patent citations and the value of innovations," RAND Journal of Economics, vol. 21, no. 1, pp.172-187, 1990.

[14] A. Pakes, "Patents as options: some estimates of the value of holding European patent stocks," Econometrica, vol. 54, no. 4, pp. 755-784, 1986.

[15] M. Schankerman and A. Pakes, "Estimates of the value of patent rights in European countries during the post-1950 period," Economic Journal, vol. 96, pp. 1052-1077, 1986.
[16] R. Blundell, R. Griffith, and J. Reene, "Dynamic count data models of technological innovation," Economic Journal, vol. 105, no. 429, pp. $333-344,1995$

[17] R. A. Connolly and M. Hirschey, "Market value and patents: a bayesian approach," Economic Letters, vol. 27, pp. 83-87, 1988.

[18] O. Toivanen, S. Paul, and B. Derek, "Innovation and the market value of UK firms, 1989-1995," Oxford Bulletin of Economics and Statistics, vol. 64, pp. 39-61, 2002.

[19] U. Ben-Zion, "The R\&D and investment decision and its relationship to the firm's market value: some preliminary results," in $R \& D$, Patents, and Productivity, Z. Griliches, Ed. Chicago: University of Chicago Press, 1984, pp. 299-312.

[20] D. Bosworth and M. Rogers, "Market value, R\&D and intellectual property: an empirical analysis of large Australian firms," The Economic Record, vol. 77, no. 239, pp. 323-337, 2001.

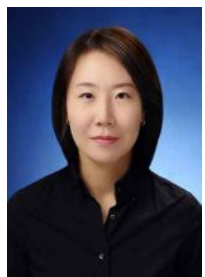

So-Jin Lim was born in Seoul, South Korea, In October 14, 1978. She received BS of life science in Korea University, 2002; MA of Economics in Seoul National University, 2005; Ph. D. of Economics in technology management, economics and policy program (TEMEP), Seoul National University, 2011. She is an associate researcher fellow in Korea Institute of Intellectual Property located in Seoul.

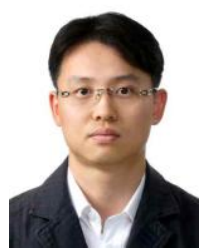

Tae-Kyu Ryu was born in Jinju, South Korea in 28th March, 1970. He received the BS degree in departmen of Electrical engineering, Seoul National University in 1998. Also, he received MS., Ph.D. degree in Economics from technology management, economics and policy program (TEMEP), Seoul National University in 2001 , 2005 respectively. He was a researcher in Technology Transfer and Commercialization Center at Korea Institute of Science and Technology (KIST) and an adjunct professor in University of Science \& Technology (UST). At present he is a research follow in Korea Institute of Intellectual Property (KIIP) located in Seoul. His research interests are technology transfer and commercialization, Policy and Strategy of Intellectual Property, Performance Measure and Indicator, and Valuation or Spillover Effect of Patent and Technology. 